\title{
AZ IDŐ ÚJJÁSZÜLETÉSE: A GALILEI-FÉLE RELATIVITÁSELV ÉS AZ EINSTEIN-FÉLE EKVIVALENCIAELV ÉRTELMEZÉSE SAMUEL ALEXANDER TÉRIDŐELMÉLETE ALAPJÁN
}

\section{TIME REBORN: UNDERSTANDING GALILEI'S RELATIVITY AND EINSTEIN'S EQUIVALENCE PRINCIPLE BASED ON SAMUEL ALEXANDER'S THEORY OF SPACE-TIME}

\author{
Paksi Dániel \\ PhD (tudományfilozófia és tudománytörténet) \\ Budapesti Müszaki és Gazdaságtudományi Egyetem Filozófia és Tudománytörténet Tanszék \\ daniel.paksi@filozofia.bme.hu
}

\section{ÖSSZEFOGLALÁS}

\begin{abstract}
A relativitáselmélet és a kvantummechanika kialakulása a pozitivista és a fizikalista filozófiai szemléletmód megerősödéséhez vezetett a tudományokban, amely mellőzte az olyan kérdéseket, mint miért abszolút a fény sebessége, vagy hogy mi a fény mint hullám terjedési közege, ma pedig nem tud megbirkózni az olyan alapvető kérdésekkel, mint hogy mi lehet az univerzum $95 \%$-át kitevő rejtélyes sötét anyag és sötét energia. Dolgozatomban amellett érvelek, hogy Lee Smolin víziójának megfelelően, illetve Samuel Alexander téridőelmélete alapján, miszerint nem az anyag vagy valamiféle szellem, hanem az idő a létező dolgok fundamentuma, lehetséges a huszadik századi fizika eredményeinek olyan nem pozitivista/fizikalista értelmezése, amely tudományos értelemben helytálló, és képes az ilyen jellegű, mellőzött és rejtélyes filozófiai kérdésekre is koherens, megalapozott választ adni.
\end{abstract}

\section{ABSTRACT}

The theory of relativity and quantum mechanics led to the rise of a new philosophy in the sciences, positivism/physicalism which neglected such basic questions, for example, that why the speed of light is absolute, or what is the medium in which light as a wave propagates. Now, it has no answers to such basic questions that what the mysterious dark energy and matter are which make up 95 percent of the whole universe. In my paper, based on Lee Smolin's vision and Samuel Alexander's theory of space-time, according to which, the fundament of reality is not matter or some kind of spirit but time, I argue that it is possible to give such a non-positivist/ physicalist account of the results of modern physics which, on the one hand, in the scientific sense, is correct, and on the other hand, is able to give coherent and well-grounded answers to these ignored and mysterious philosophical questions. 
Kulcsszavak: emergencia, téridő, anyag, fizika, relativitáselmélet, pozitivizmus, Albert Einstein, Lee Smolin, Samuel Alexander

Keywords: emergence, space-time, matter, physics, theory of relativity, positivism, Albert Einstein, Lee Smolin, Samuel Alexander

\section{BEVEZETÉS}

Szélesebb körben is közismertek azok a konceptuális problémák (hullám-részecske kettősség, determinizmus vs. indeterminizmus kérdése stb.), amelyek Albert Einstein relativitáselmélete és a kvantummechanika kialakulásával jöttek létre. Ráadásul ezek a problémák azóta csak súlyosbodtak, hiszen például rádöbbentünk, hogy a világegyetem nagy részét az ún. sötét energia és sötét anyag alkotja, amelyekről gyakorlatilag nem tudunk semmit. Ennek ellenére a fizikusok és a filozófusok többsége, mellőzve ezeket az alapvető kérdéseket, ma is a lassan száz éve jól megszokott, ún. pozitivista/fizikalista utat járja, amely természetesen nem más, mint egy modern, sajátos materializmus. Én azonban ebben a dolgozatban a szük kisebbség útkeresését fogom követni - konkrétan a fizikus Lee Smolinét (2011) -, akik megpróbálnak szakítani ezzel a régóta meddő, de továbbra is uralkodó szemléletmóddal. Smolin Az idö újjászületése címü könyvében a következőképpen fogalmazza meg az alaptételét: „Az idő bizonyul majd a mindennapi tapasztalatunk egyetlen olyan elemének, amely tényleg alapvetö. Az a tény, hogy mindig valamilyen pillanatot érzékelünk, és hogy ezt a pillanatot úgy tapasztaljuk meg, mint ami egyike a pillanatok egymásra következő sorának, nem illúzió. Ez a legbiztatóbb jelünk, amely az alapvető valóság nyomára fog vezetni.” (Smolin, 2014, 32.)

Az időről szerzett tapasztalatunk tehát nem illúzió, az idő a valóság fundamentuma. Fontos látni, hogy ez egy filozófiai állítás. Ahogy például az is filozófiai állítás volt Isaac Newton részéről, hogy a térdidő egy anyagtól független abszolút létező. A kérdés tehát az, hogy mit jelent, hogy nem az anyag, hanem az idő a „tényleg alapvető" létező, és hogy hogyan lehet erre a filozófiai elvre fölépíteni egy új, koherens megközelítésmódot.

Smolin nincs vele tisztában, de az elképzelése valójában egyáltalán nem új, hanem majdnem százéves. Samuel Alexandernek, az emergentizmus megalapítójának ugyanis pontosan ugyanez volt a kiindulópontja Space, Time, and Deity címü magnum opusában (1920), mielőtt a pozitivista/fizikalista szemléletmód teljesen eluralta volna a tudományokat.

A tanulmányban a relativitáselv és az idő mint tényleg alapvető létező közötti összefüggés lényegére fogok fókuszálni, a mellőzött számos tudománytörténeti és technikai részletet az érdeklődő olvasó a Personal Reality (2019b), illetve a 
hamarosan megjelenő, Az emergencia fogalma (2019a) című könyveimben találhatja meg, a mainstream pozitivista/fizikalista filozófiai megközelítés problémáit pedig a Fizikalizmus gyenge lábakon címü cikkemben (2017).

\section{A TÉNYLEG ALAPVETŐ LÉTEZŐ ÉS A RELATIVITÁSELMÉLET}

Az Einstein-féle relativitáselmélet legfontosabb alapja a Galilei-féle relativitáselv, amelyet Einstein az ún. ekvivalenciaelvvel gyorsuló rendszerekre és magára a gravitáció jelenségére is kiterjesztett. A relativitáselv eme következetesebb alkalmazása vezetett a newtoni abszolút téridő elképzelés elvetéséhez. A 20. század elején azonban még úgy tünt, hogy a relativitáselv ellentmondásban van a fényterjedés törvényszerüségével, amely azt mondja ki, hogy a fény vákuumban minden vonatkoztatási rendszerhez képest állandó $c$ sebességgel terjed. Ez azt jelenti, hogy a fény mozgása a többi mozgással szemben nem relatív, hanem abszolút. Einstein a relativitáselmélettel ezt a szerinte látszólagos ellentmondást szerette volna feloldani (Einstein, 1978, 26-27.).

Galilei a relativitáselvet az arisztotelészi tudománnyal szemben fogalmazta meg. Arisztotelész azt állította, hogy a világegyetemnek van egy abszolút centruma (vonatkoztatási rendszere), amely mind a földi, mind az égi gravitációs mozgásokat meghatározza: a Földön a dolgok egyenes vonalú mozgással a világegyetem középpontja felé esnek, kitüntetett nyugalmi pozíciót foglalva el a folyamat végén, az égben pedig körmozgást végeznek eme abszolút középpont körül. Galilei viszont elvetette, hogy a világegyetemnek lenne egy ilyen abszolút centruma, és azt állította, hogy nincs lényeges különbség földi és égi mozgások között. Galilei példájával élve ez azt jelenti, hogy a földi testek éppen ugyanolyan elv szerint esnek a Föld centruma felé, ahogy a holdi testek a Hold centruma, a napbeli testek pedig a Nap centruma felé stb. (Galilei, 1959, 24.), vagyis minden önálló testnek megvan a maga relativ centruma, relatív vonatkoztatási rendszere. Ez a relativitáselv filozófiai alapja.

Galilei azonban kiterjesztette a gondolatmenetet a lendületmegmaradás jelenségére, és azt a fizikai következtetést vonta le, hogy a nyugalom és az egyenes vonalú egyenletes mozgás fizikai értelemben azonos (ekvivalens) állapotok, egyik sem kitüntetett a másikhoz képest, vagyis valójában csak a tudós által megválasztott vonatkoztatási rendszer kérdése, hogy az adott test nyugalomban van, vagy egyenletes haladó mozgást végez, például hogy az ürhajó mozog a Földhöz vagy éppen a Föld az ürhajóhoz képest. Ha nincs egy kitüntetett vonatkoztatási rendszer, illetve ha nincs jelen gyorsulás, amely a gyorsulást kiváltó anyagi erőhatás miatt egyértelművé tenné, hogy melyik a valódi mozgás, akkor nem lehet eldönteni, hogy valójában melyik test mozog.

Mindebből pedig az is látszik, hogy a relativitáselv eme eredeti, Galilei-féle fizikai értelmezése miért nem érvényes gyorsuló rendszerekre. Einstein ezt 
a problémát tekintette a relativitáselv legnagyobb hiányosságának, és a saját bevallása szerint ennek a kiküszöbölése ösztönözte az általános relativitáselmélet kidolgozására (Einstein, 1978, 75.).

Newton nem gondolta azt, hogy a fenti kérdés eldönthetetlen lenne. A mozgástörvényeket ugyan a relativitáselv figyelembevételével fogalmazta meg, a rendszerébe azonban beépítette az ,abszolút, igaz és matematikai” téridő elképzelését is (Newton, 1846, 77.). A világegyetem arisztotelészi centrumához hasonlóan ez az az abszolút vonatkoztatási rendszer, amelyhez képest el lehet dönteni, hogy valójában a Föld vagy az ürhajó mozog.

Fontos látni, hogy Newton az elképzelését a legkevésbé sem a tapasztalatra építette, sőt, az ,abszolút, igaz és matematikai” idő elképzelését kifejezetten a tapasztalatban adott, szerinte „relatív, látszólagos és hétköznapi” idővel szemben fogalmazta meg (Newton, 1846, 77.). Az időt a tapasztalatainkban ugyanis igen eltérő, relatív sebességgel és módokon éljük meg, mint például irreverzibilis fizikai idő, biológiai idő (például öregedés, evolúció), pszichológiai idő (például emlékezés) stb. Newton állításából - Smolin hétköznapi tapasztalatra épülő alaptételével szemben - az következik, hogy ezek a jelenségek éppen olyan illuzórikusak, mint ahogy azt érzékeljük, hogy a Föld mozdulatlanul áll a lábunk alatt. Az idő valójában abszolút és matematikai, ami praktikusan azt jelenti, hogy a téridő megfeleltethető egy absztrakt, végtelen négydimenziós Descartes-féle koordináta-rendszernek. Newton tehát a relatív/tapasztalati téridőből egy abszolút/matematikai időt gyártott, az időt pedig a tér puszta negyedik dimenziójává fokozta le. Az időt azonban Smolin megfogalmazásában Einstein üzte ki végleg a tudományokból (Smolin, 2014, 86-107.).

Fontos azt is látni, hogy a Galilei-féle fizikai értelmezésben már maga a relativitáselv sem a tapasztalatra építkezik, önmagában ugyanis, vagyis anélkül, hogy mechanikai értelemben egy másik testhez (jellemzően a mozdulatlannak tekintett, de valójában nagyon is mozgó földfelszínhez) rögzítenénk, egyetlen test sincs sem nyugalomban, sem pedig egyenletes haladó mozgásban, mivel a gravitációs erő hatóköre végtelen, ráadásul Newton szerint azonnali, vagyis idő nélkül terjed. Eltekintve tehát a gyorsuló mozgásoktól, Galilei a relativitáselv fizikai értelmezését valójában azért fogalmazta meg, hogy azt a gyakorlatban alkalmazni tudja bizonyos konkrét fizikai/mechanikai problémák megoldására kizárólag anyagi testek, lassú sebességek, illetve földi körülmények között. Ha ugyanis tisztán a tapasztalatra építkezünk, akkor a relativitáselv a nyugalom és a gyorsulás azonosságát fogja jelenteni: az a test, amely a saját vonatkoztatási rendszeréből nyugalomban van, a másikéból gyorsulónak fog tủnni. Ehhez a felismeréshez azonban egy Einsteinre volt szükség.

A fizikusok számára a tapasztalat végül a fényterjedés törvényszerüsége révén kérdőjelezte meg a Galilei-féle relativitáselvet, kiderült ugyanis, hogy a fény sebessége abszolút. A példánkkal élve ez azt jelenti, hogy hiába megy az ürhajó a 
Földhöz képest $v$ sebességgel, a fény sebessége a nyugvó Föld és a mozgó ürhajó rendszeréből is $c$ lesz. Einstein szerint a fizikusok többsége emiatt a relativitáselv elvetését fontolgatta, ő maga azonban egy másik utat választott: a newtoni abszolút téridő koncepcióját vetette el (Einstein, 1978, 27-28.).

Matematikailag Einstein megoldása mindössze annyi, hogy a fizikai számításokba bevezette az ún. Lorentz-transzformációt. Ez azt jelenti, hogy bár a $v$ sebességgel haladó ürhajóhoz képest a fény ténylegesen kisebb távolságot fog megtenni, mint a nyugalomban lévő Földhöz képest, mégsem fog úgy tünni, hogy $v$ sebességgel lassabban halad, mint az abszolút $c$ fénysebesség, ugyanis a Lorentz-transzformációnak megfelelően a $v$ sebességgel haladó óra pont annyival fog lassabban járni az ürhajón, hogy a fény sebessége továbbra is $c$-nek fog mutatkozni. Mindez pedig azért lehetséges, mert nincs newtoni abszolút téridő és vonatkoztatási rendszer. Vagyis: „Minden vonatkoztató testnek (koordináta-rendszernek) megvan a saját külön ideje; az időadatnak csak akkor van értelme, ha a vonatkoztató testet is megadjuk, amelyre az időadatok vonatkoznak." (Einstein, 1978, 33-35.)

A kérdés csak az, hogy milyen értelemben van az objektumoknak „,saját külön idejük", ha azoknak semmi értelmük egy másik vonatkoztatási rendszer megadása nélkül. Ez a probléma a következőképpen jelenik meg: tegyük fel, hogy van egy ikerpár, akik közül az egyik a Földön tartózkodik, a másik pedig egy ürhajón. Az ürhajó a Földhöz képest egyenletesen halad $v$ sebességgel. Tekintsük a két testet egymás vonatkoztatási rendszerének. Ebböl az következik, hogy a $v$ sebességgel haladó ürhajón az idő lassabban telik, ami úgy híresült el a köztudatban, hogy az ürhajón lévő iker lassabban öregszik. Ugyanakkor mivel a relativitáselv következetesebb alkalmazásának megfelelően nincs abszolút vonatkoztatási rendszer, a következő állítás is tökéletesen helytálló: a Föld $v$ sebességgel halad az ürhajóhoz képest. Amiböl pedig az következik, hogy a Földön lassabban telik az idő, tehát a Földön lévő iker lassabban öregszik. Most akkor ki öregszik lassabban, melyik állítás az igaz?

A talán meglepő válasz az, hogy egyik sem. Ugyanis Einstein félrevezető megfogalmazása ellenére a relativitáselmélet semmilyen állítást nem fogalmaz meg arra nézve, hogy a valóságban milyen idejük van a különböző objektumoknak. Csak annyit állít, hogy különböző vonatkoztatási rendszereket felvéve (például a Földet) a fizikai modellezés során milyennek tünik egy bizonyos másik objektum (például egy, a Földhöz képest $v$ sebességgel haladó ürhajó) számított ideje annak érdekében, hogy a Galilei-féle relativitáselv és a fényterjedés törvénye közötti látszólagos ellentmondás megszűnjön a fizika matematikai rendszerén belül.

Newton szerint az idő egy anyagtól független abszolút/matematikai létezö. Einstein szerint (a fizikalista felfogásnak megfelelően) csak az anyagi pontokat (vagyis a testek fizikai modelljeit) tekinthetjük önálló létezőknek, a tér és az idő ezeknek az anyagi pontoknak a relatív tulajdonsága (Einstein, 1978, 93-94.), 
amelyet tehát úgy adhatunk meg, hogy egy tetszőlegesen kiválasztott vonatkoztatási rendszerből kiszámoljuk a különböző anyagi pontokhoz rendelhető téridőértékeket. A téridő ezeknek az adatoknak a relativimatematikai rendszere.

Kérdés persze, hogy az anyagi pontok hogyan/hol léteznek egyáltalán, ha a téridő nem valóságos, hanem csak a különböző anyagi pontok relatív $\mathrm{x}_{1}, \mathrm{x}_{2}, \mathrm{x}_{3}, \mathrm{x}_{4}$ értékei. Egyetlen létező sem létezhet a saját tulajdonságában. Ez a kérdés természetesen azzal a híres konceptuális problémával analóg, hogy hogyan létezhet egy hullám, vagyis a fény, ha nincs semmiféle közeg, amelynek a hulláma lehetne, illetve hogyan lehet valami egyszerre pontszerü részecske és egy (nem létezö) közeg hulláma. A pozitivista szemléletmód sajátja, hogy eltekint az ilyen logikai ellentmondásoktól, alapvető kérdésektől.

Newton tehát elvonatkoztatott az időről meglévő relatív tapasztalatainktól, és megfogalmazta az abszolút/matematikai idő koncepcióját. Ám Einstein sem tért vissza az idő tapasztalati elemzéséhez, hanem a pozitivista tudományos modellezés szellemében megalkotta az idő relatív/matematikai koncepcióját. Ráadásul nem állt meg ezen a ponton, hanem az ekvivalenciaelv megfogalmazásával a relativitáselvet kiterjesztette gyorsuló rendszerekre is. Egy híres példával élve: az ürben lebegő (nyugalomban lévő) ürhajós és a Földön, például egy liftben zuhanó (gyorsuló) ember állapota fizikai értelemben ekvivalensek egymással, mind a ketten a súlytalanság állapotában vannak. A két állapot azért lehet ekvivalens, mert a zuhanó embert valójában nem éri semmiféle erőhatás, vagyis nemcsak Newton abszolút téridő, de gravitációs erő koncepciója is téves: valójában nem azt érzékeljük, ahogy a (nem létező) gravitációs erő lefelé húz, hanem azt, hogy a padló felfelé nyom bennünket. Einstein eredeti példáját modernizálva mindez tehát azt jelenti, hogy ha egy ürhajós nem tudná, hogy ő valójában egy ürhajón tartózkodik, amely g-vel, vagyis a földi gravitációs gyorsulás mértékével gyorsul, akár azt is hihetné, hogy ő valójában a Földön áll nyugalomban (Einstein, 1978, 69-70.). Vagyis a gravitációs erőtérben nyugvó és gyorsuló rendszereket fizikai értelemben ekvivalensnek tekinthetjük, és mindenféle gond nélkül ugyanazzal a matematikai apparátussal, azaz a „görbe” Gauss-koordináták rendszereivel modellezhetjük.

Azért kell itt már határozottan modellezésröl és nem valóságról beszélnünk, mert lehet, hogy a modellezés során (egy konkrét dimenzióban) úgymond a Földön lévő gravitációs erőteret gyorsulássá transzformálhatjuk, vagy éppen fordítva, nyugvó gravitációs erőtérként kezelhetjük a $g$-vel gyorsuló űrhajós állapotát az űrhajón, ez azonban természetesen nem fogja azt jelenteni, hogy a $g$-vel gyorsuló ürhajó ténylegesen nyugalomban van (ne érné konkrét anyagi erőhatás, amelynek révén gyorsul), sem azt, hogy a Föld felszínén nyugalomban álló ember a padló nyomása miatt $g$-vel gyorsulna felfelé. Einstein figyelmeztetésében: „Mármost könnyen azt lehetne hinni, hogy a gravitációs tér létezése csak látszólagos, és hogy bármilyen is a gravitációs tér, mindig választható egy másik olyan 
vonatkoztató test, amelyre nézve nincs gravitációs tér. Ez azonban semmi esetre sem áll minden gravitációs térre, hanem csakis az egészen különleges felépítésủekre. Így például lehetetlen úgy megválasztani egy vonatkoztatási rendszert, hogy belőle nézve a Föld nehézségi erőtere (teljes egészében) eltünjék." (Einstein, 1978, 72.)

Einstein állításának az az oka, hogy ahhoz, hogy a Föld gravitációs tere (teljes egészében és ne csak egy konkrét dimenzióban) kitranszformálható legyen, olyan vonatoztatási rendszerre lenne szükség, amelyhez képest a Föld egyszerre három dimenzióban összesen hat különböző irányban gyorsul. Ez pedig Einstein szerint nyilvánvalóan lehetetlen: egy anyagi test nem gyorsulhat egyszerre hat irányban.

\section{ALEXANDER TÉRIDŐELMÉLETE ÉS A GALILEI-FÉLE RELATIVITÁSELV}

Ha viszont nem az anyag, hanem az idő a tényleg alapvetö létező, az azt jelenti, hogy az anyag is időből áll, pontosabban fogalmazva a téridőből alakul ki, emelkedik ki. Ezt az idő dinamikus természetéből fakadó kiemelkedést, ahogy például az eredeti anyagi „őslevesből” kiemelkedett az élet, nevezi Alexander az emergencia folyamatának. A dolgok létezésének nincs semmi további anyagi vagy éppen szellemi alapja azon túl, hogy a keletkezésüktől (vagy éppen a születésüktől) kezdve a szétbomlásukig (vagy éppen a halálukig) fennállnak a rájuk jellemző térben és időben, legyen szó egy kvantumról vagy egy amőbáról. Ami a számunkra most azt jelenti, hogy a Föld mint téridőbeli létező képes a téridőben egyszerre hat irányba gyorsulni.

Alexander szerint tapasztalati alapon az időnek három alapvető tulajdonsága van: (1) öröklődő, vagyis egy folytonos egészet képez, az egymást követő időpillanatok egymásra épülnek, például a ma nem marad ki a tegnap és a holnap között; (2) irreverzibilis, vagyis az idő határozott iránnyal rendelkezik, és ennek megfelelően az időpillanatok múlt, jelen, jövő struktúrával rendelkeznek; (3) tranzitív, vagyis az idő megőrzi és átörökíti a korábban megszerzett tulajdonságait, például a múlt nem válik jövővé (Alexander, 1920, I/50-52.). Mindez azt jelenti, hogy az idő dinamikus természettel bír, folytonos mozgásban van, újabb és újabb időpillanatok jönnek létre, illetve azt, hogy az idő átfogó struktúrával bír.

Ezzel szemben a térnek önmagában nincs semmiféle átfogó struktúrája és dinamizmusa, ugyanis a térpontok önmagukban teljesen azonosak egymással, nem lehet különbséget tenni egy adott térpont és akár végtelen számú másik térpont között sem. Ez azt jelenti, hogy a tér önmagában nem tekinthető létezőnek, pusztán a téridőtől elvonatkoztatott matematikai absztrakciónak, amelynek a pontjait például önkényesen megválasztott Gauss-koordinátákkal különböztetjük meg egymástól. 
Bár az időnek a térrel szemben határozott tulajdonságai vannak, önmagában mégsem tekinthető létezőnek, ugyanis nincs saját tere, amelyben a dinamizmusa meg tudna nyilvánulni. Az idö ennek megfelelöen csak és kizárólag a tér különbözö pontjaiban, részeiben tud megnyilvánulni. Ami azt illeti, Alexander elképzelése szerint, mivel a térnek önmagában nincs semmiféle átfogó struktúrája, így saját dimenziója sem, a téridőnek a három dimenzióját is magának az időnek a tér különböző pontjaiban való megnyilvánulása hozza létre, pontosabban fogalmazva, az idő újabb és újabb dinamikus megnyilvánulása hozza létre az újabb és újabb térpontokat. Az így létrejövő téridőnek pedig azért lesz három és nem több vagy kevesebb dimenziója, mert a térpontokban megnyilvánuló idő három alapvető tulajdonsággal rendelkezik (Alexander, 1920, I/52-56.).

Az idő tehát nem egy absztrakt/matematikai negyedik dimenzió, hanem a háromdimenziós téridő alkotóeleme, pontosabban fogalmazva, a téridő (magasabb szintü, átfogó) rendezöelve, amely az adott lehetöségfeltételben (alacsonyabb szintü részletekben), vagyis jelen esetben a térpontokban megnyilvánulva meghatározza a téridő alapvető struktúráját és mozgásait. Ez az emergencia logikája, és ez a folyamat újabb és újabb formában magasabb szinteken is végbemegy, például az idő újabb megnyilvánulása a téridő egy specifikus terében a fizikai idő és az anyag kialakulásához vagy még magasabb szinten, például bizonyos kémiai molekulák specifikus feltételei között, vagyis sajátos terében a biológiai idő és az élet kialakulásához vezet.

Az, hogy az idő a tényleg alapvető létező, Alexander szerint tehát azt jelenti, hogy az idő a valóság végső rendezőelve: maga a valóság, azaz az univerzum az idő első dinamikus megnyilvánulásával jön létre a térben, amely az elméletből fakadóan az első pillanatban még nem más, mint egyetlen pont. Ez konkrétan azt jelenti, hogy az univerzum a kezdeti állapotában egy végtelen szingularitás: mivel az idő dinamikus természetének megfelelően mozgásban van, matematikai értelemben mind a sürüsége, mind a hőmérséklete végtelennek tekintendő. Ez azonban csak egyetlen pillanatig tart, mert az idő dinamikus természetének megfelelően máris újabb és újabb térpontok jönnek létre: az egyetlen pontpillanatként megszülető univerzum rohamos táguláson megy keresztül.

Ha az idő a valóság végső fundamentuma, rendezőelve, akkor értelemszerüen a fényterjedés törvényszerüsége, vagyis a fény mozgása is az idő dinamikus megnyilvánulásának a következménye. Ha viszont a fénysebesség az idő alapvető mozgásának az eredménye, akkor abból az következik, hogy a kezdetekkor az univerzum a fénysebességnél jóval nagyobb sebességgel tágult, ugyanis az idő eme legalapvetőbb megnyilvánulása akkor még egy viszonylag kevés térpontból álló térben ment végbe, vagyis a meglévő térpontokhoz képest relatíven sok új térpontot hozott létre (a tér minden pontján és a tér minden irányában). Mivel ez a tér ma, több mint tizenhárom milliárd évvel később pontosan ugyanaz a tér, mint az eredeti végtelen szingularitás tere (csak éppen az idő alapvető meg- 
nyilvánulásának köszönhetően ma már gyakorlatilag végtelen pontból áll), az idő eme eredendő megnyilvánulása most is minden térpontban jelen van, csak éppen relatíven sokkal kisebb aktivitással. Ugyanakkor, ha az előbbi tényező a meghatározóbb, akkor az univerzum továbbra is gyorsulva tágul. A téridő önmagában nem más, mint mozgás (fizikai kifejezéssel élve „sötét” energia).

Miután létrejött a téridő, ez olyan új lehetőségfeltételeket, olyan új, magához a térhez képest magasabb szintü, specifikus tereket hozott létre a téridőben, amelyek lehetővé tették az idő újabb típusú (fizikai) megnyilvánulásait: létrejöttek az első anyagi típusú létezők. Alexander ezeknek az anyagi létezőknek a beazonosítását és kategorizálását már a fizikai területének tekinti, de azt megjegyzi, hogy a fény és a hozzá hasonló létezők feltehetően teljesen más típusú anyagi létezök, mint az atomi típusúak, és talán az elektrontípusúakat is külön kategóriába sorolhatjuk (Alexander, 1920, II/53-54.). A standard modellben egy évszázaddal később megkülönböztetik egymástól a bozonokat (közvetítő részecskéket, mint a fény) és a fermionokat (anyagi részecskéket), amelyeken belül létezik a kvarkok (atomot alkotó részecskék) és a leptonok külön csoportja, ahová az elektron is tartozik; ezeknek a taglalására mint az idő különböző háromdimenziós dinamikus megnyilvánulásai ebben a dolgozatban azonban most nincs mód.

Alexander elképzelésének a lényege az anyagra és az anyag alapvető mozgásaira vonatkoztatva mindenesetre a következő: Mivel az első szingularitás tere és a mindenkori tér ugyanaz a tér, az univerzumnak nincs kitüntetett/abszolút centruma. Minden mozgás és létezés csak és kizárólag az idő dinamikus természetének, bizonyos konkrét megnyilvánulásának a következménye. Máshogyan fogalmazva, mivel tapasztalati alapon a téridő nem abszolút, minden létezőnek megvan a maga saját ideje, amely meghatározza az adott dolog téridőbeli létezését és mozgásait, vagyis az idő minden egyes konkrét megnyilvánulása a $s a$ ját centrumának, saját relatív vonatkoztatási rendszerének tekintendő. Az idő azonban elválaszthatatlan a tértől, mindig csak konkrét terekben nyilvánul meg, van jelen, például magasabb szinten az én biológiai időm kizárólag az én testem sajátos terében, ami szó szerint az én létezésemet jelenti a rám jellemző sajátos mozgásokkal.

Ha az idő dinamikus megnyilvánulása a nyitott térben történik, mert például bizonyos („fény típusú”) létezők bizonyos dimenziója esetében az azokat alkotó idő továbbra is ilyen nyitott módon, magában a téridőben nyilvánul meg, akkor (még) nem egy időbeli létezést, hanem egy egydimenziós térbeli egyenletes haladó mozgást kapunk. Ha azonban az idő egy zárt térben nyilvánul meg, vagyis egy specifikus, magasabb szintű lehetőségfeltétel mellett, akkor a legegyszerübb esetben egy kétdimenziós körmozgást kapunk, amelynek lesz egy önmagában nyugalomban lévő centruma. Ez az idő második legalapvetőbb megnyilvánulása a térben. Ebben az esetben ennek a (zárt típusú) létezőnek az ideje (a létrejötté- 
től a felbomlásáig) elkülönül magától a téridőtől, aminek köszönhetően, sajátos, újonnan megjelenő (magasabb szintü) tulajdonságokra és azokból fakadó mozgásokra tesz szert, az idejét pedig ennek megfelelően immár nem pusztán (a térben megnyilvánuló) időnek, mozgásnak, hanem (egy konkrét anyagi létező specifikus terében megnyilvánuló) fizikai időnek kell tekintenünk; konkrétan ez az idő/mozgás jelenti ennek az anyagi létezőnek a létezését.

Az új tulajdonságok és mozgások elött azonban most elöször azt a kérdést tegyük fel, hogy mit jelent mindez a Galilei-féle relativitáselvre nézve: vajon a fény sebessége egy $v$ sebességgel haladó ilyen zárt típusú létezőhöz képest is megma$\operatorname{rad} c$-nek? Magyarul összeegyeztethetö-e Alexander elmélete a speciális relativitáselmélettel? A válasz az, hogy igen, ugyanis Alexander elméletében minden (létezés és) mozgás magából az időből fakad, vagyis ha egy ilyen létező valamilyen oknál fogva sebességre tett szert, amelyet az idő tranzitív természete miatt megörzött (vagyis fizikai nyelven a lendületmegmaradás elve miatt), akkor a fizikai ideje (létezése) részben ebben a mozgásban fog megnyilvánulni. Konkrétan, ebből az egyszerü elvből magát a Lorentz-transzformációt is le lehet vezetni. A lényeg azonban az, hogy a $v$ sebességgel haladó létező mérhető fizikai ideje így éppen annyival lesz kevesebb, hogy a fény sebessége továbbra is $c$-nek fog tünni, ahogy azt a speciális relativitáselmélet számításai megkövetelik, és ahogy azt korábban az ürhajós példánknál láthattuk.

Arra a kérdésre pedig, hogy mindezt miért lehet megtenni Alexander elméletére építkezve, a válasz a következő: Egyrészt azért, mert Alexander téridőelmélete teljes összhangban van a Galilei-féle relativitáselv mélyebb filozófiai jelentésével, vagyis hogy az univerzumnak nincs egy abszolút centruma, amely meghatározná a különböző mozgásokat, hanem éppen ellenkezőleg, minden egyes létezőnek saját relatív centruma van, és az így megnyilvánuló idő határozza meg a mozgásait. Másrészt pedig azért, mert a fényterjedés törvényszerüsége már eleve is következik Alexander elméletéből: vannak olyan (,fény”) típusú létezők, amelyeknek az egyik dimenziójában az idő nem fizikai időként, hanem tiszta mozgásként nyilvánul meg (ami egyébként konkrétan azt jelenti, hogy a mérhető fizikai idejük ebben a dimenzióban nulla, ismertebb megfogalmazásban fénysebességnél az idő megáll).

Ráadásul Alexander elmélete alapján többet is állíthatunk, mint Einstein, ugyanis nemcsak az anyagi pontokat, hanem a téridő relatív/emergens pontpillanatait is vonatkoztatási rendszernek választhatjuk, ami miatt egyértelmúvé válik, hogy az eredeti példánkban tényleg nem a Föld fog $v$ sebességgel száguldani (bár persze ilyen fizikai modellezéseket, számításokat is végezhetünk, ha akarunk), hanem az ürhajó, és így az ürhajós iker fog kevésbé öregedni. A téridő ebben az esetben azonban természetesen nem azért lesz valódi/kitüntetett vonatkoztatási rendszer, mert abszolút, ahogy azt Newton rendszerében láthattuk, hanem „csak” azért, mert minden anyagi test és anyagi mozgás valódi (relatív/emergens) 
eredete. Ehhez viszont természetesen Alexander elméletét is általánosítani kell tudnunk gyorsuló rendszerekre, ami visszavezet bennünket az említett új tulajdonságokhoz és mozgásokhoz, vagyis a fizikai idő eredetéhez. A problémát egy kérdés felől szeretném megvilágítani.

Einstein általános relativitáselmélete a modern fizika egyik alapja, egy hihetetlenül sikeres elmélet. A kérdés az, hogy hogyan lehet a gyorsuló és a nyugvó gravitációs rendszerek ekvivalenciaelvre épülő egységes matematikai modellezése ilyen sikeres, ha egyébként valójában ezek a rendszerek nem azonosak egymással, vagyis például Einstein figyelmeztetésének megfelelően a Föld mint gravitációs rendszer valójában a legkevésbé sem gyorsul a gravitációs tér mind a hat irányába. Az uralkodó pozitivista filozófiai szemlélet felől ez egy fölösleges kérdés, pedig a válasz egyértelmü: sehogyan. Einstein relativitáselmélete azért müködik, mert egy mélyebb filozófiai értelemben tényleg tökéletes az ekvivalencia a nyugalomban lévő gravitációs rendszerek és a gyorsuló rendszerek között, ami szó szerint azt jelenti, hogy a Föld és a hozzá hasonló rendszerek olyan nyugalomban lévő gravitációs erőtérrel rendelkező rendszerek, amelyek a gravitációs erőtér minden dimenziójának minden irányában gyorsulnak - és nem lehet egyetlen kivétel sem, különben az ekvivalencia nem lenne valódi.

Az ürhajós példájával megvilágítva a problémát: az ürhajós gyorsuló fizikai állapota nemcsak analóg, vagyis matematikai értelemben egyformán modellezhető a Föld felszínén nyugalomban lévő megfigyelő fizikai állapotával, hanem a két fizikai állapot filozófiai értelemben is tökéletesen azonos, mind a két megfigyelő ténylegesen gyorsul. Az egyedüli különbség az, hogy az ürhajós egy konkrét anyagi hatás következtében gyorsul felfelé, míg a Föld felszínén lévő megfigyelő a Föld gravitációs hatása miatt gyorsul felfelé, konkrétan a padló nemcsak jól érzékelhető módon nyom bennünket felfelé, miközben a hatás eredményeképpen valójában nem történik semmi, hanem éppen úgy gyorsulunk felfelé, ahogy az ürhajós. A másik híres példánkkal megvilágítva a kérdést: a liftben zuhanó megfigyelő súlytalan fizikai állapota nemcsak analóg az ürben elhelyezkedő megfigyelő súlytalan fizikai állapotával, hanem tökéletesen azonos, mind a liftben zuhanó, mind az ürben lévő megfigyelö tökéletes nyugalomban van. Valójában ugyanis nem a liftben zuhanó megfigyelö gyorsul a Föld felszíne felé, hanem a Föld felszine gyorsul a nyugalomban lévö megfigyelö felé (akit csak természetes hétköznapi nézöpontunk miatt nevezünk zuhanónak), és ez az oka annak, hogy a liftben lévő megfigyelő a súlytalanság állapotában van: semmiféle gravitációs hatás vagy gyorsulás nincs jelen a liftben, mindössze a Föld gyorsulásáról beszélhetünk ama tértartomány irányába, amelyet a nyugalomban lévő lift elfoglal.

Mindennek pedig megint csak az a magyarázata, hogy Alexander elméletében minden mozgás a relatív/emergens idő dinamikus megnyilvánulásának a követ- 
kezménye: ennek megfelelően (1) a téridő is valódi, állandóan mozgásban lévő létező, (2) a téridőből kiemelkedő anyagi létezők az eredetük révén (fizikai) időből állnak, (3) a Galilei-féle relativitáselv pedig mind az anyagi testekre, mind a téridőre tökéletesen érvényes. Ahogy a legegyszerübb anyagi létező esetében láthattuk, ha az idő egy zárt térben nyilvánul meg, vagyis egy sajátos, magasabb szintü lehetőségfeltétel mellett, akkor egy kétdimenziós körmozgást kapunk, amelynek lesz egy önmagában nyugalomban lévő centruma. A létező így (1) mint anyagi létezö az anyagi szinten nyugalomban van, vagyis konkrét zárt struktúrával és anyagi tulajdonságokkal rendelkezik a saját relatív/emergens centrumához rögzítve, ugyanakkor a körmozgásnak köszönhetően (2) mint idő a téridő szintjén a körmozgás minden irányában gyorsul. Ez azonban a relativitáselvnek megfelelően az anyagi létező vonatkoztatási rendszeréböl (centrumából) azt fogja jelenteni, hogy az anyagi létezöt körülvevö téridö gyorsul az anyagi létezö nyugalomban lévö centruma felé.

Az idő zárt térben való eme második legalapvetőbb megnyilvánulása, vagyis a gravitáció jelensége éppen úgy „nyeli el” magát a téridőt, mint ahogy az idő legalapvetőbb megnyilvánulása megteremti azt. És persze mindez megint csak teljes összhangban van azokkal a megfigyelésekkel, amelyeket a nagy tömegü csillagászati objektumok, elsősorban fekete lyukak téridőben való viselkedéséről szerezhetünk az elmúlt évtizedekben. A fizikai időt tehát, mint most már láthatjuk, anyagi szinten (nyugalmi) tömegnek nevezzük. Maga a gravitáció jelensége azonban nem anyagi kölcsönhatás, hanem a téridő mozgása, és ez az oka annak, hogy az emergencia logikájának megfelelően nem egyesíthető a magasabb szintủ anyagi kölcsönhatásokkal. A legegyszerübb anyagi létező, amely még semmilyen más összetettebb anyagi tulajdonsággal és mozgással (kölcsönhatással) nem rendelkezik a fizikai időn/tömegen és az abból fakadó gravitációs mozgáson túl, pedig természetesen nem más, mint amit sötét anyagnak neveztünk el.

A gondolatmenet kulcspontja tehát valójában az, amit kérdésként tettünk fel, hogy Alexander téridőelméletét Einstein ekvivalenciaelvéhez hasonlóan kiterjeszthetjük-e gyorsuló rendszerekre. A válasz pedig az, hogy nemcsak hogy kiterjeszthetjük, de a tapasztalati alapon megalkotott relatív/emergens téridő elképzelése valójában eleve magában foglalja mind a Galilei-féle relativitáselv filozófiai alapját, mind a gyorsuló és nyugalomban lévő rendszerek ekvivalenciáját. A Föld természetesen már egy jóval összetettebb, ráadásul élettel teli létező, mint a sötét anyag, de az alapjait tekintve éppen olyan téridőbeli anyagi létező, és éppen úgy kiváltja a gravitáció jelenségét. Einstein elképzelésével szemben tehát azért lehet nyugalomban és gyorsulhat egyszerre hat különböző irányban, mert az idő a tényleg alapvető létező, és a relativitáselv a téridőre is éppen úgy érvényes, mint az anyagi létezőkre. Mindez persze a Föld számunkra triviálisnak tekintett vonatkoztatási rendszeréből azt jelenti, hogy nem a lift 
vagy más, önmagában nyugalomban lévő és így súlytalan anyagi test zuhan lefelé, hanem a relativitáselvnek megfelelően a relatív/emergens téridő mozog a Föld gyorsuló/nyugalomban lévő centruma felé, magával hozva a térben nyugalomban lévő testeket. Ezt az idő mint tényleg alapvető létező dinamikus természetéből fakadó valódi jelenséget lehet a relativitáselv és az ekvivalenciaelv fizikai/matematikai értelmezésével olyan kiválóan modellezni Gauss-koordináták „görbe” rendszereivel.

\section{KONKLÚZIÓ}

Az Alexander-féle emergenciaelv a Galilei-féle relativitáselv és az Einstein-féle ekvivalenciaelv általánosabb filozófiai megfogalmazása. Ez az oka annak, hogy összhangban van az Einstein-féle relativitáselmélet fizikai állításaival, sőt képes annak mélyebb filozófiai értelmezését adni.

Smolinnak tehát igaza van: a tényleg alapvető létező az idő, ami Alexander elméletében azt jelenti, hogy a relatív/emergens idő különböző megnyilvánulási formáiban a különböző szintű létezők és mozgások alapvető rendezőelve. A világ fundamentuma nem az anyag és nem is valamiféle szellem, hanem maga az idő.

Az idő legalapvetőbb, egydimenziós megnyilvánulása a térben maga a tiszta, anyagtalan mozgás, amely először a téridő/univerzum robbanásszerü megszületéséhez (ösrobbanás és kozmológiai infláció), majd máig tartó gyorsuló tágulásához vezetett (,sötét energia”). Az idő következő, kétdimenziós megnyilvánulása azután a fizikai idő és a gravitációs mozgások létrejöttéhez vezetett (,sötét anyag”). Az idő különböző háromdimenziós megnyilvánulásai hozzák létre ezek után az anyag alapvető típusait („fény típusú” és „elektron típusú” létezők, illetve a kvarkok). Az emergencia itt nem állt meg, az idő sajátos megnyilvánulása bizonyos kémiai molekulák specifikus, magasabb szintü terében a biológiai idő, vagyis az élet és az evolúciós folyamat (mozgás/fejlődés) kialakulásához vezetett stb.

Alexander emergens téridőelmélete közel százéves, és megdöbbentő összhangban van az elmúlt száz év tudományos felfedezéseivel. A modern fizika, ahogy Smolin törekvéseiben láthattuk, azonban csak most jutott el arra a pontra, hogy egy ilyen típusú útkeresés esetleg megkezdődhessen. Amennyiben persze a fizikusok és a mainstream intézmények képesek lesznek a fizika és a tudomány érdekében feladni igen erőteljes pozitivista/fizikalista filozófiai meggyőződéseiket, és egy új filozófiai szemüvegen keresztül tekinteni az elmúlt évszázad tudományos felfedezéseire. 


\section{IRODALOM}

Alexander, S. (1920): Space Time and Deity. London: MacMillan and Co. https://openlibrary.org/ books/OL7177641M/Space_time_and_deity

Einstein, A. (1978): A speciális és áz általános relativitás elmélete. (ford. Vámos F.) Budapest: Gondolat Kiadó

Galilei, G. (1959): Párbeszédek a két legnagyobb világrendszerröl, a ptolemaiosziról és kopernikusziról. Budapest: Európa Könyvkiadó

Newton, I. (1846): The Mathematical Principles of Natural Philosophy. New York: Daniel Adee, https://archive.org/details/newtonspmathema00newtrich

Paksi D. (2017): Fizikalizmus gyenge lábakon. A materializmus interpretációja Samuel Alexander téridö-elméletének a fényében. Magyar Filozófiai Szemle, 61, 3, 87-112. http://filozofiaiszemle.net/wp-content/uploads/2018/01/Paksi-D\%C3\%A1niel-Fizikalizmus-gyenge-1\%C3\%A1bakon.pdf

Paksi D. (2019a): Az emergencia fogalma. Budapest: L’Harmattan Kiadó (megjelenés alatt)

Paksi D. (2019b): Personal Reality. The Emergentist Concept of Science, Evolution, and Culture. 1-2. Eugene, OR, USA: Pickwick Publications

Smolin, L. (2011): Mi a gubanc a fizikával? A húrelmélet problémái és a lehetséges kiutak. Budapest: Akkord Kiadó

Smolin, L. (2014): Az idő újjászületése. Budapest: Akkord Kiadó 